University of Nebraska - Lincoln

DigitalCommons@University of Nebraska - Lincoln

Egyptian textiles and their production: 'word' and 'object'

Centre for Textile Research

$3-2-2020$

Reconstruction of a deconstructed tunic

Anne Kwaspen

University of Copenhagen, Saxo Institute

Follow this and additional works at: https://digitalcommons.unl.edu/egyptextiles

Part of the Africana Studies Commons, African Languages and Societies Commons, Classical Archaeology and Art History Commons, Fiber, Textile, and Weaving Arts Commons, History of Art, Architecture, and Archaeology Commons, and the History of Science, Technology, and Medicine Commons

Kwaspen, Anne, "Reconstruction of a deconstructed tunic" (2020). Egyptian textiles and their production: 'word' and 'object'. 6.

https://digitalcommons.unl.edu/egyptextiles/6

This Article is brought to you for free and open access by the Centre for Textile Research at DigitalCommons@University of Nebraska - Lincoln. It has been accepted for inclusion in Egyptian textiles and their production: 'word' and 'object' by an authorized administrator of DigitalCommons@University of Nebraska - Lincoln. 


\title{
Reconstruction of a deconstructed tunic
}

\author{
Anne Kwaspen
}

\section{Introduction}

Tunics of the $1^{\text {st }}$ millennium AD can be classified into two main groups according to the direction of the warp in the finished tunic. ${ }^{1}$ The first group of tunics has horizontal warp threads in the finished tunic. This means that the cloth as it is worn is rotated $90^{\circ}$ from the weave direction on the loom. ${ }^{2}$ In the second group of tunics the warp runs vertically in the finished tunic. Each group of tunics has their typical technological features and finishing methods, with additional distinctions between wool and linen tunics. ${ }^{3}$ This article focuses on the study of a tunic belonging to the first group with horizontal warp and all technical features that are discussed below are related to this type only.

In addition, tunics can be subdivided depending on whether they have sleeves. Within the group of tunics with horizontal warp, numerous tunics with woven-on sleeves are in museum collections, but sleeveless tunics are unusual. Most of these sleeveless tunics are made of wool and are small children's tunics. Even though they are represented on mosaics and paintings, only a few wool tunics for adults are known from excavation reports or museum collections. 4

The Louvre Museum has in its collection one colourful sleeveless wool tunic (AF 12249), which, according the dimensions (height $=112 \mathrm{~cm}$ and $117 \mathrm{~cm}$ with fringes, width $=89 / 93 \mathrm{~cm}$, circumference neck opening $=58 \mathrm{~cm}$, arm opening $=+/-32 \mathrm{~cm}$, distance shoulder line-waist tuck $=56 \mathrm{~cm}$ ), is clearly for an adult (fig. 1). Although very fragile, this tunic has not yet undergone conservation treatment, so the weave is not yet fixed on a support fabric. It was therefore possible to analyse details of both the inside and outside of the tunic.

\section{Weave and design}

The cloth is woven with a red wool warp (S-spun), 9 threads/cm. Red, green, yellow and natural-coloured wool (S-spun), supplemented with natural-coloured linen (Sspun), was used as weft yarn. The number of weft threads, $22 / \mathrm{cm}$, is well above the number of warp threads, as a result of which the weave has a weft-faced tabby structure. However, the warp is not completely covered by the weft, which gives a mottled effect in the yellow and green stripes. After finishing the weave the warp was worked into two different finishing borders, with a twisted border on one side and a braided border on the other. ${ }^{5}$

The design of the weave is formed by small and wider stripes running from hem to hem. A small plain green stripe at the outermost edge is followed by a plain yellow stripe. Next comes a wide green stripe, followed by a

Published in Maria Mossakowska-Gaubert, ed., Egyptian Textiles and Their Production: 'Word' and 'Object' (Hellenistic, Roman and Byzantine Periods) (Lincoln, NE: Zea Books, 2020). doi 10.32873/unl.dc.zea.1083

1. Description of the different types of tunics: Kwaspen \& Verhecken-Lammens 2015.

2. Detailed description of the construction of tunics: Verhecken-Lammens 1993, p. 41-52; Verhecken-Lammens 1994.

3. See Kwaspen \& Verhecken-Lammens 2015.

4. Catalogue of sleeveless tunics in museum collections and published archaeological sites: Morgan 2018, p. 149-150.

5. Description and drawings of different finishing borders: Verhecken-Lammens 1997, p. 94-95. 


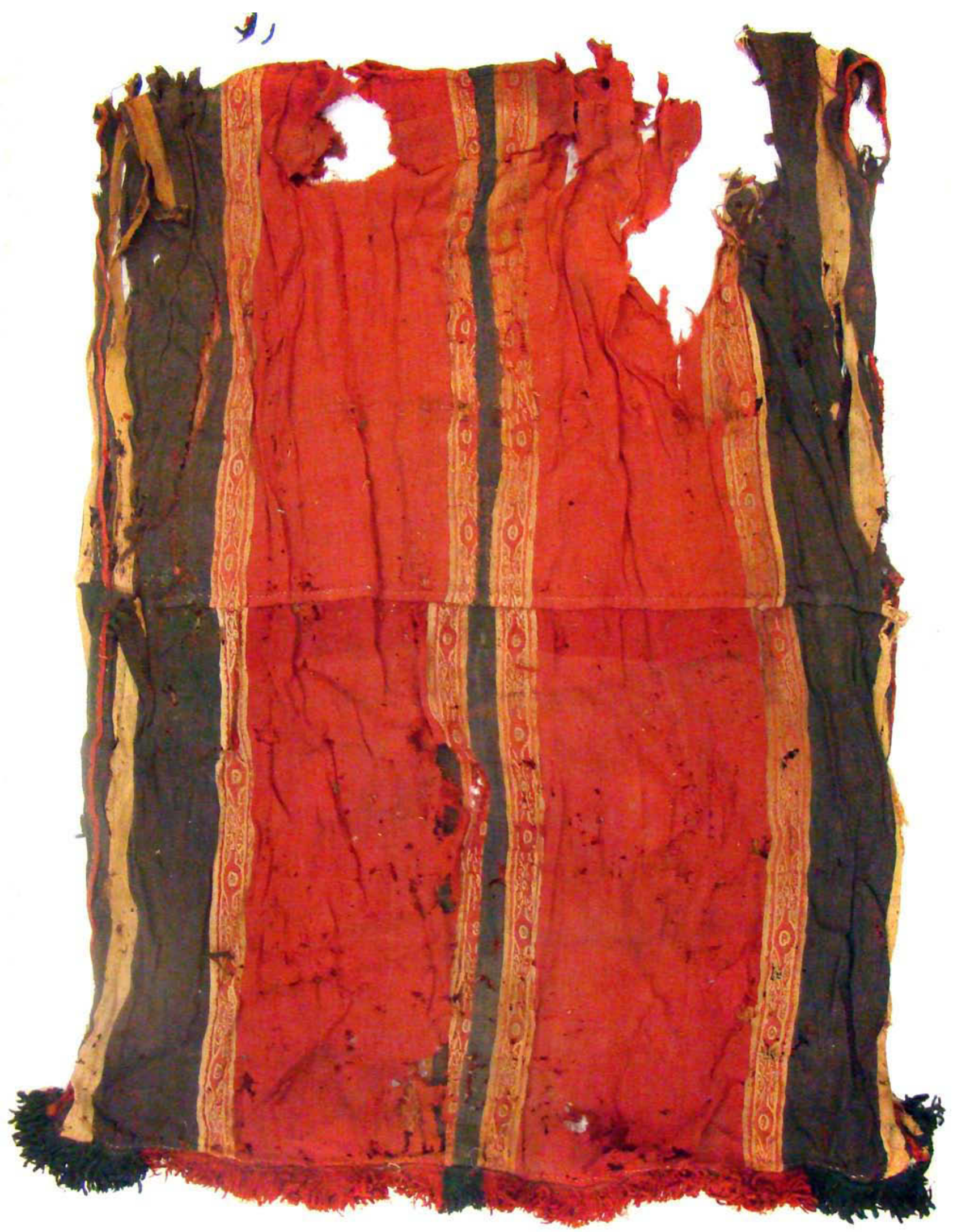

Figure 1. Tunic AF 12249. Musée du Louvre. (Photo: Anne Kwaspen (C) Musée du Louvre). 

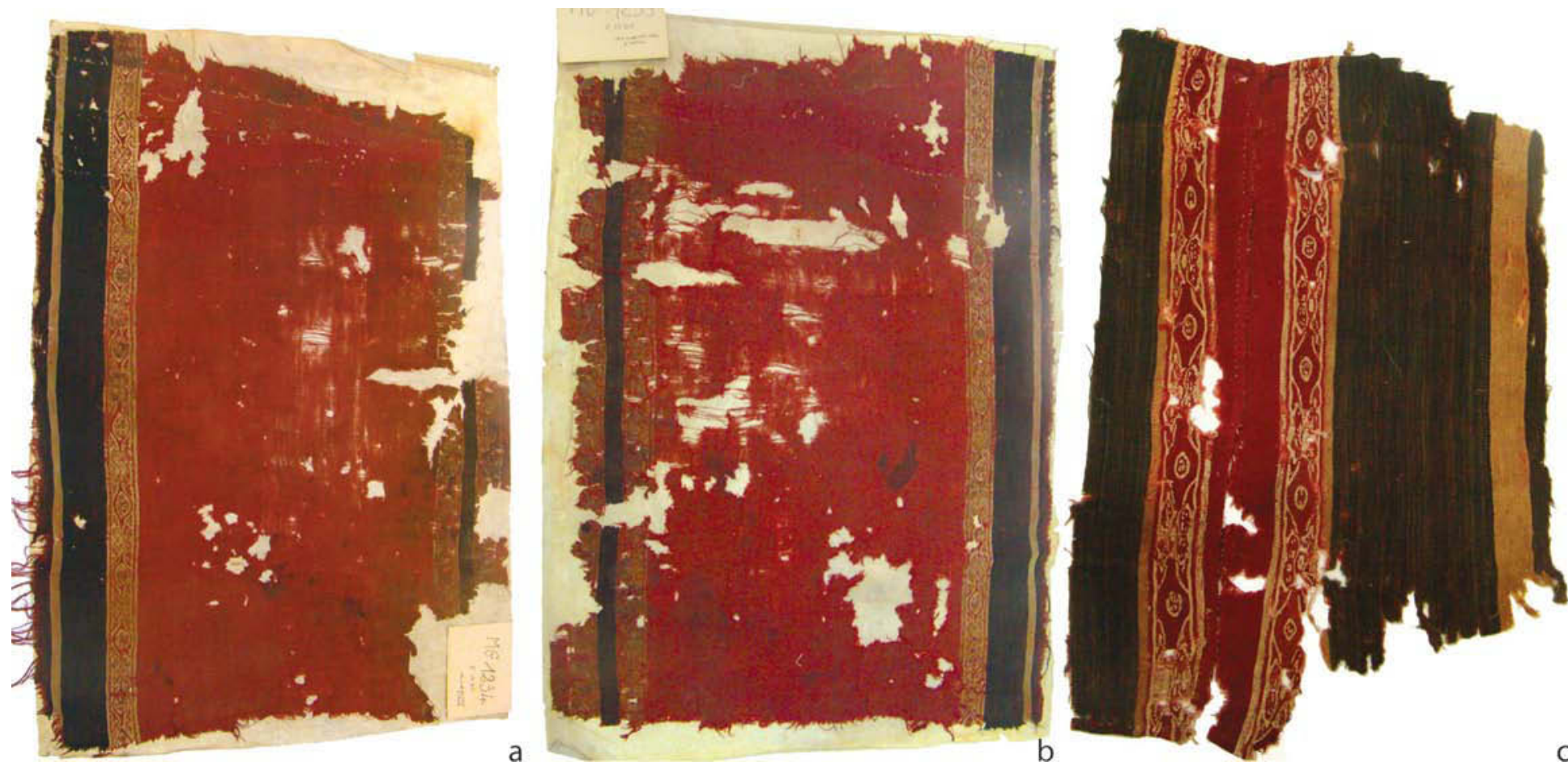

Figure 2. a. Fragment E 29306; b. Fragment E 29308; c. Fragment AF 5989. Musée du Louvre. (Photos: Anne Kwaspen (c) Musée du Louvre).

patterned stripe in white, yellow and red. Next is a significantly wider red stripe. In the centre of the tunic two similar patterned stripes flank a small plain green stripe. The other side of the weave mirrors the first part described above. The patterned stripes consist of two small yellow stripes on the outsides, with yellow wave motifs on a red background next to it in the middle. The central decoration of the stripe is woven in slit tapestry technique with eccentric wefts, where eye-shaped motifs alternate with fine unidentifiable stylised plant motifs.

Wool tunics patterned with woven-in tapestry bands held in museum collections display a considerable variety of decoration and use of colour. It is therefore rather exceptional to find the same type of patterning on tunics (fragments) in different collections. The Louvre Museum has three other wool fragments, E 29306, E 29308 and AF
5989, with similar design and woven in the same colours (fig. 2). Fragments E 29306 and E 29308 even have the same sequence of stripes as tunic AF 12249. In addition, the Museum für Byzantinische Kunst in Berlin (inv. 11467) ${ }^{6}$ and Bolton Museum (inv. 26.1914.34) ${ }^{7}$ have a comparable fragment in their collection.

\section{Wool tunic in three parts}

All published and more or less complete sleeveless wool tunics are woven in one piece, ${ }^{8}$ where a wide warp (full length of the tunic from hem to hem) was placed on the loom, requiring probably two weavers working side by side to weave it. ${ }^{9}$ It was therefore surprising to discover that this tunic AF 12249 consists of three parts. Of wool tunics woven-to-shape with sleeves, few examples made in

6. Fluck et al. 2000, p. 65-67.

7. Pritchard 2013, p. 38-39.

8. BM 2004,0910.5 in Morgan 2018, p. 100; the Phoebus Foundation KTN 789-02, KTN 789-03 and KTN 741: in De Moor et al 2008 p. 162-163 and Kwaspen \& Verhecken-Lammens 2015, p. 154; Abegg-Stiftung 4219: in Wild 1994, p. 9-36; V\&A 6361886: in Kwaspen \& Verhecken-Lammens 2015, p. 154; Qustul (Nubia), grave Q150 20349: in Mayer Thurman, p. 69.

9. Pritchard 2006, p. 45. 

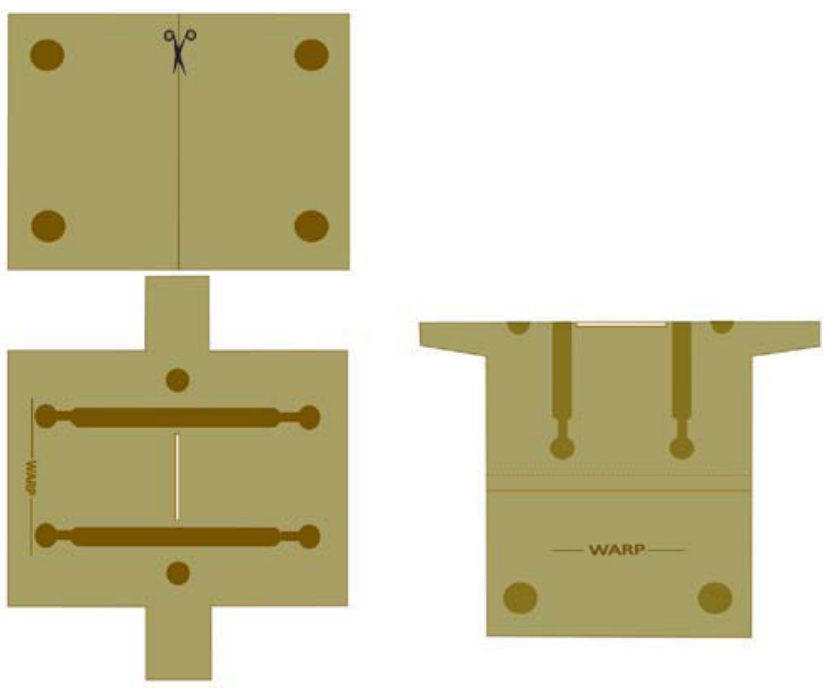

Figure 3. Drawing of a woven-to-shape tunic in three parts. (Drawing (c) Anne Kwaspen).

three parts are known. ${ }^{10}$ Instead of a complete warp, only the warp needed for the upper part was set up on a small loom. ${ }^{11}$ The length of the warp is calculated for weaving the width of the woven-to-shape upper part followed by a second part to create the lower parts of the tunic. To construct the tunic, this second part is divided in two equal parts, to form the front and back 'skirt' of the tunic. These parts are sewn to the upper part along the waistline, the seam being hidden inside the waist tuck. The selvedges of the upper part form the seam together with the cut edge of the lower parts (fig. 3).

On investigation of the waist tucks of the front and back of tunic AF 12249, no selvedges were found on the upper part. On both sides the upper part has cut edges instead (fig. 4).

\section{The neck opening}

Most sleeveless wool tunics have a woven-in neck slit, constructed on the loom. The selvedges of the neck slits are always reinforced either by grouping warp threads or most often by bringing supplementary warp yarns into the structure. These extra warp yarns are held and divided by weft countered twining on one side, and eliminated by working

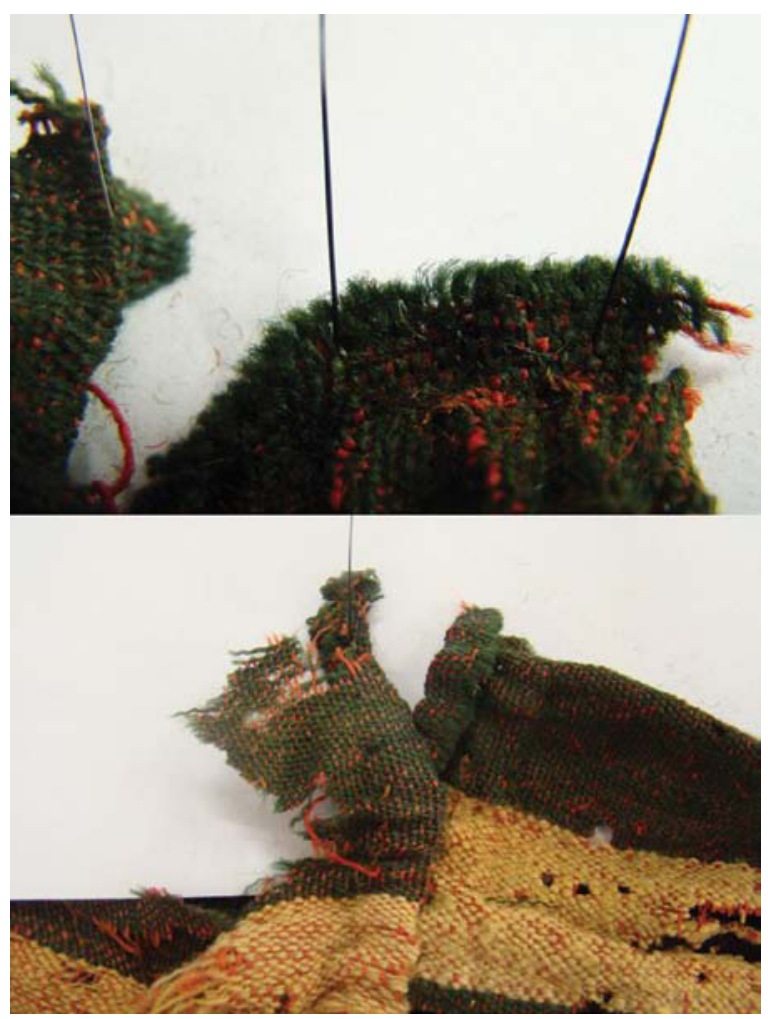

Figure 4. Tunic AF 12249. Detail of waist tuck: cut edges. (Photo: Anne Kwaspen (c) Musée du Louvre).

these extra threads into countered twining on the other side. The slit corners are also strengthened by weft twining. ${ }^{12}$

Tunic AF 12249 is also an exception with regard to the neck opening, because it is cut. The finishing of this cut-out opening is also unusual. Generally, the edge of the opening would be folded to the outside and then finished with an applied trimming, but in this tunic the edge is turned towards the inside as a rolled seam. No reinforcement by weft twining near the neck opening is detected, which could indicate an alteration of the neck opening after it had been damaged.

\section{Weft twining}

3-3 weft twining can be found, however, at two unexpected places in the weave. Several red wool yarns are (counter) twined in weft direction from the hem and tuck upwards only on the front side of the tunic (fig. 5).

10. Examples known and analysed by the author: Victoria \& Albert Museum, London, V\&A 291-1891: published in Haldane 2009, and Haldane \& Persson 2019; Museum of Applied Arts, Vienna, MAK T1, MAK 10758, see online catalogue: https:// sammlung.mak.at/sammlung_online?id=collect-260097 (last checked: 28/6/2019) and https://sammlung.mak.at/sammlung_ online?id=collect-108210 (last checked: $28 / 6 / 2019$ ).

11. Verhecken-Lammens 1993, p. 43-45.

12. Kwaspen 2017. 


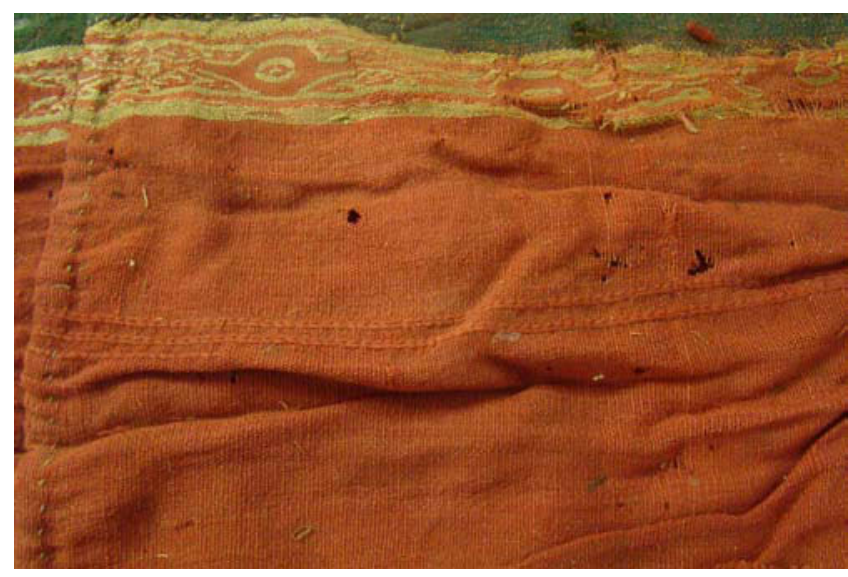

Figure 5. Tunic AF 12249. Detail with weft twining from waist tuck upwards. (Photo: Anne Kwaspen (c) Musée du Louvre).

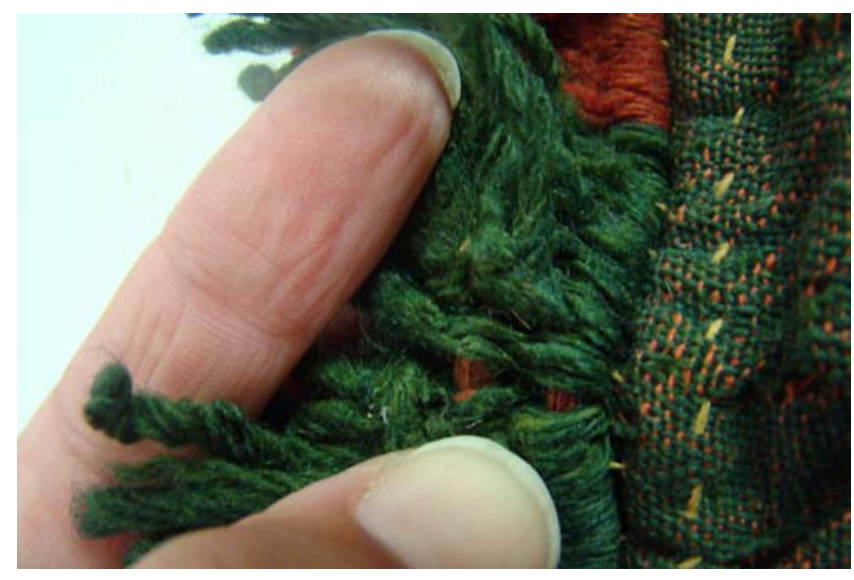

Figure 6. Tunic AF 12249. Detail of hem with applied fringed trimming. (Photo: Anne Kwaspen (c) Musée du Louvre).

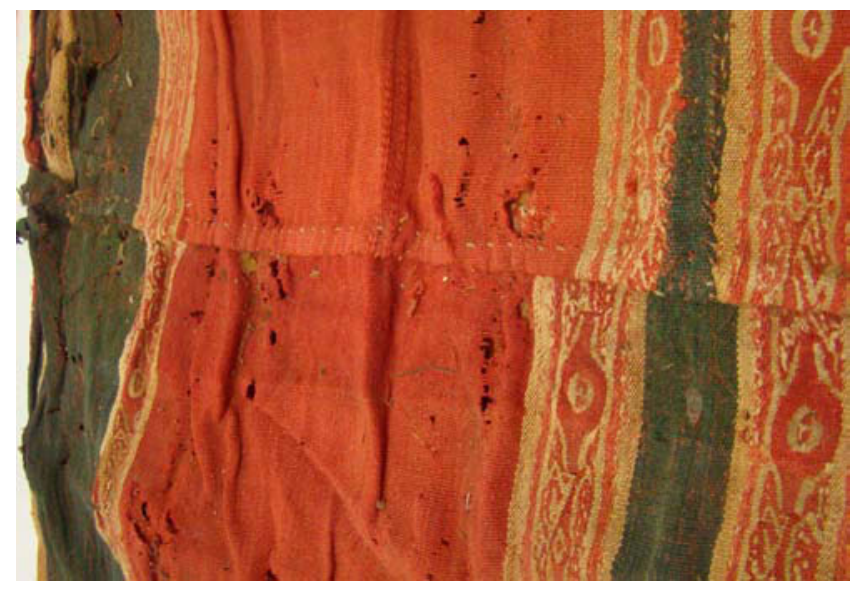

Figure 7. Tunic AF 12249. Detail of weave near tuck: band of brighter coloured wool just below the tuck. (Photo: Anne Kwaspen (C) Musée du Louvre).

\section{The hem}

As was often made on tunics, fringes are created at the hem of the tunic. As described above, in general for tunics in three parts, the lower parts of the tunic were woven in one piece and then cut in half in warp direction and turned $90^{\circ}$ before being sewn to the upper part. The selvedges then logically become the hem of the tunic. Weft fringes can thus be woven into both selvedges. ${ }^{13}$ These weft fringes then form the finishing on the hem of the tunic. As turned out with the neck opening and the waist seam, the way the hem of tunic AF 12249 is finished is different than would be expected. There are no selvedges visible on the hem but instead the hem has a rolled seam. A fringed trimming was sewn over that seam. This also explains why the colours of the fringes do not match the colours of weft threads that are in line with each other (fig. 6).

\section{The waist tuck}

Tunic AF 12249 has a small tuck of $1.2 \mathrm{~cm}$ in which the waist seam is hidden. Just below this tuck a band is visible where the colour is clearly much brighter than the bleached colours in the surrounded areas. The brighter band is not straight but wider towards the sides of the tunic (fig. 7). This kind of colour difference is often found on Egyptian wool tunics woven-to-shape and this usually indicates an opened waist tuck. These shaped, brighter-coloured bands are also visible on the other fragments of the Louvre Museum E 29306 and E 29308, and here the remains of the sewing thread to close the tuck are even preserved (fig. 2). This supports the assumption that the colour difference on tunic AF 12249 also came from an opened tuck.

The rest of the weave was examined to see if there was another similar colour difference elsewhere, and one was indeed unexpectedly found on the shoulder line (fig. 8). On this place in the tunic it is impossible that the colour differences would have occurred due to the creation of a sewn pleat, because that would mean that the neck opening would have been hidden inside this pleat.

\section{Reconstruction of the original tunic}

All the deviations compared to the usual technical features of sleeveless tunics described so far led to the assumption that this tunic was composed of cloth from another textile. However, it was by examining the unusual discoloration of the weave in the shoulder area that it became clear how another tunic was cut to create this new tunic.

13. Verhecken-Lammens 1993, p. 75-76. 


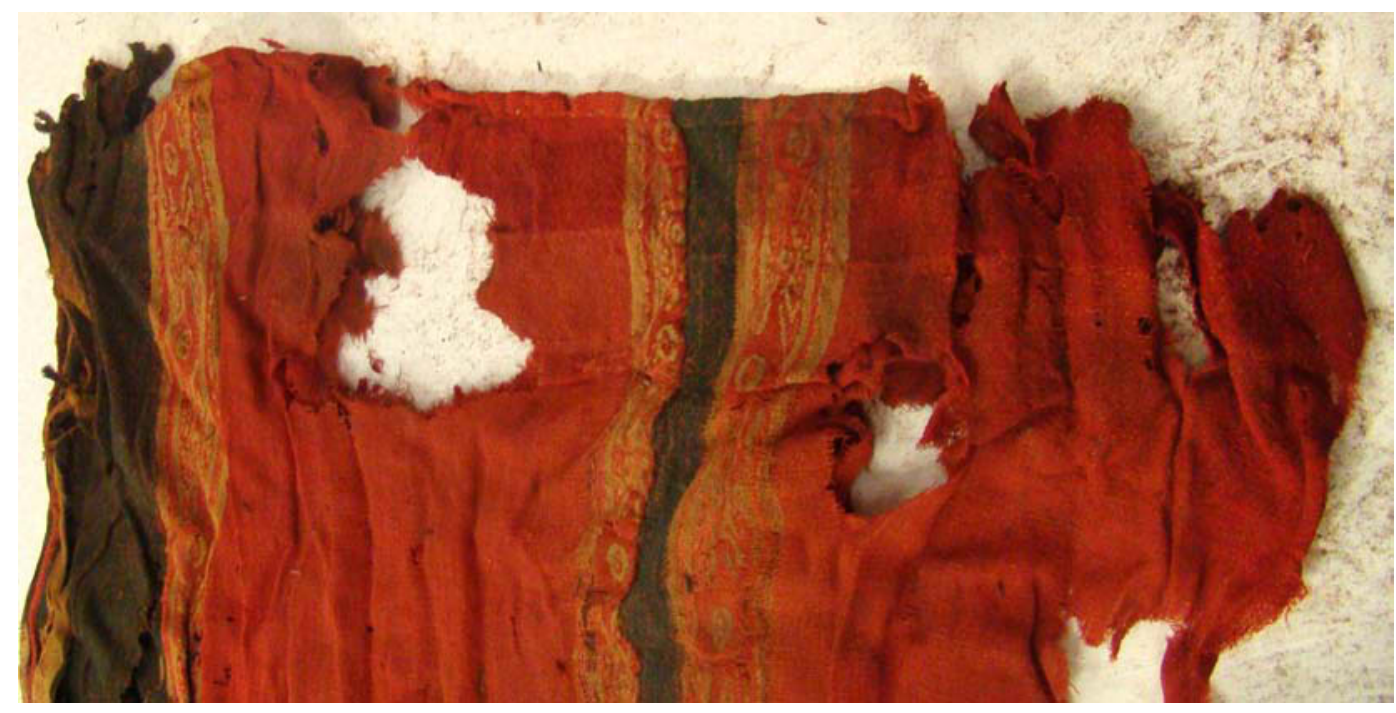

Figure 8. Tunic

AF 12249. Detail of shoulder-neck: band of brighter coloured wool. (Photo: Anne Kwaspen (C) Musée du Louvre).
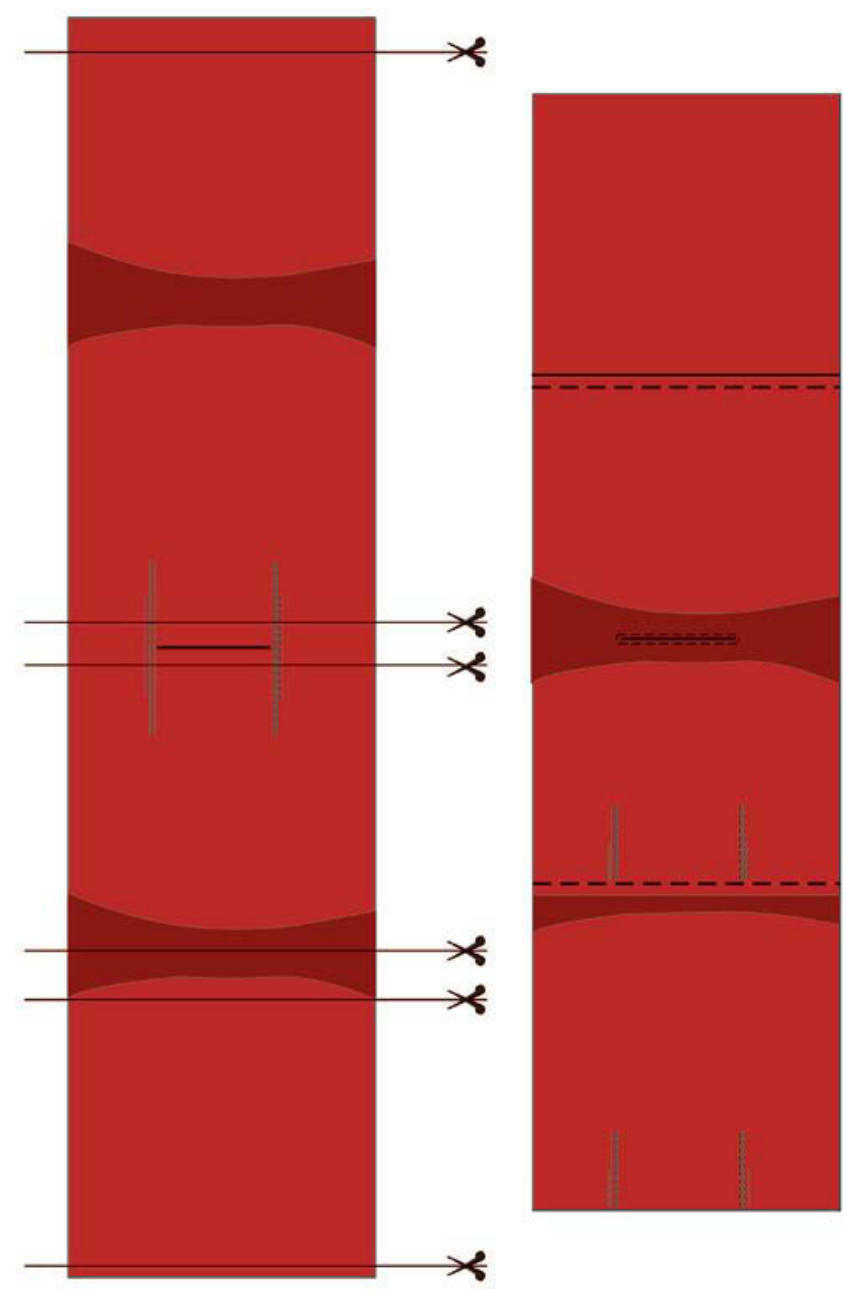

Figure 9. Drawing indicating how the original tunic was cut (left) to construct the new tunic (right). (Drawing (C) Anne Kwaspen).

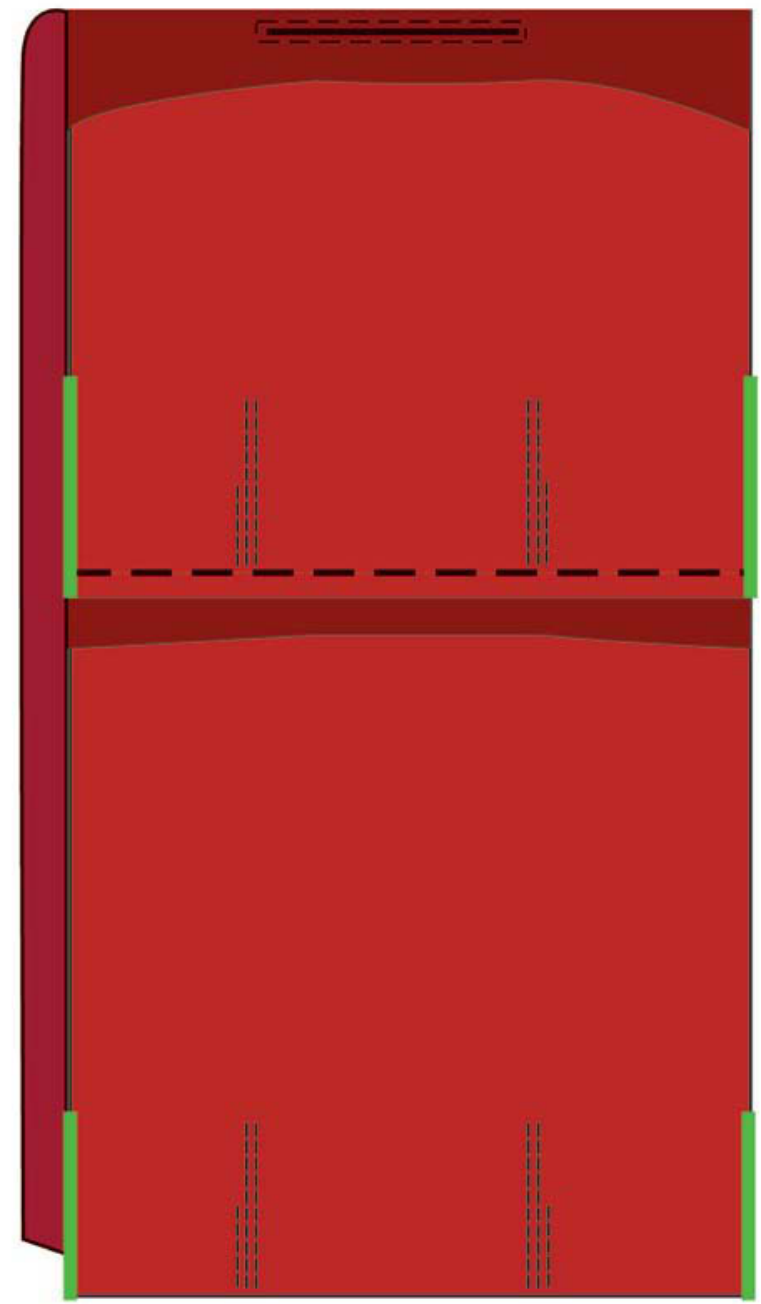

Figure 10. Drawing with green marks indicating the places with "fake" finishing borders. (Drawing (C) Anne Kwaspen). 
One could assume that the shoulder area with neck opening of the original tunic, woven in one piece, was too damaged and the cloth of the tunic has therefore been reused to create another tunic. According to the technical details in the newly formed tunic, the damaged tunic was cut as shown in fig. 9. The 'front' part of the original tunic became the upper part of the new tunic, in which it was necessary to cut a new neck opening. In this way, the ends of the weft twining on the shoulder-neck of the original tunic come to lie at the waist tuck. The other half of the original tunic is cut in two pieces through the opened original tuck. The skirt part is used as the skirt part of the back of the new tunic and the upper part is turned upside down and also used as a skirt part. This turning of the upper part results in the new tunic having the rows of the original reinforcement weft twining on the hem.

The new hem is finished with a rolled seam. The inside of the rolled seam on the back of new tunic could not be examined to see if a selvedge of the original hem was kept. The fringes that are sewn onto the hem could be the cut off fringes from the hem of the original tunic.

\section{Sleeves}

After determining the re-use of the cloth of a tunic to form this sleeveless tunic, the side edges of this newly formed tunic were examined. As described above, the warp yarns are worked into finishing cords, with a twisted cord on one side and a braided cord on the other. But at four places on the front side of the tunic (green marks at fig. 10) the warp cords stop and the sides there are finished with sewn-on twined cords. These four places correspond to what used to be the shoulder area in the original tunic. After further analysis of the weaving structure under these sewnon cords, some fragments of weaving were discovered that extend beyond the 'finishing borders', indicating that the original tunic must have been a tunic with woven-on sleeves (fig. 11). However, information about the dimensions (length, width) of the sleeves cannot be retrieved anymore because part of the original shoulder-neck part is missing.

\section{Adjustments}

Many of the Egyptian tunics in museum collections show alterations and repairs. A distinction must be made between repairs executed in late antiquity and the adjustments made by art dealers or even museum staff in the $20^{\text {th }}$
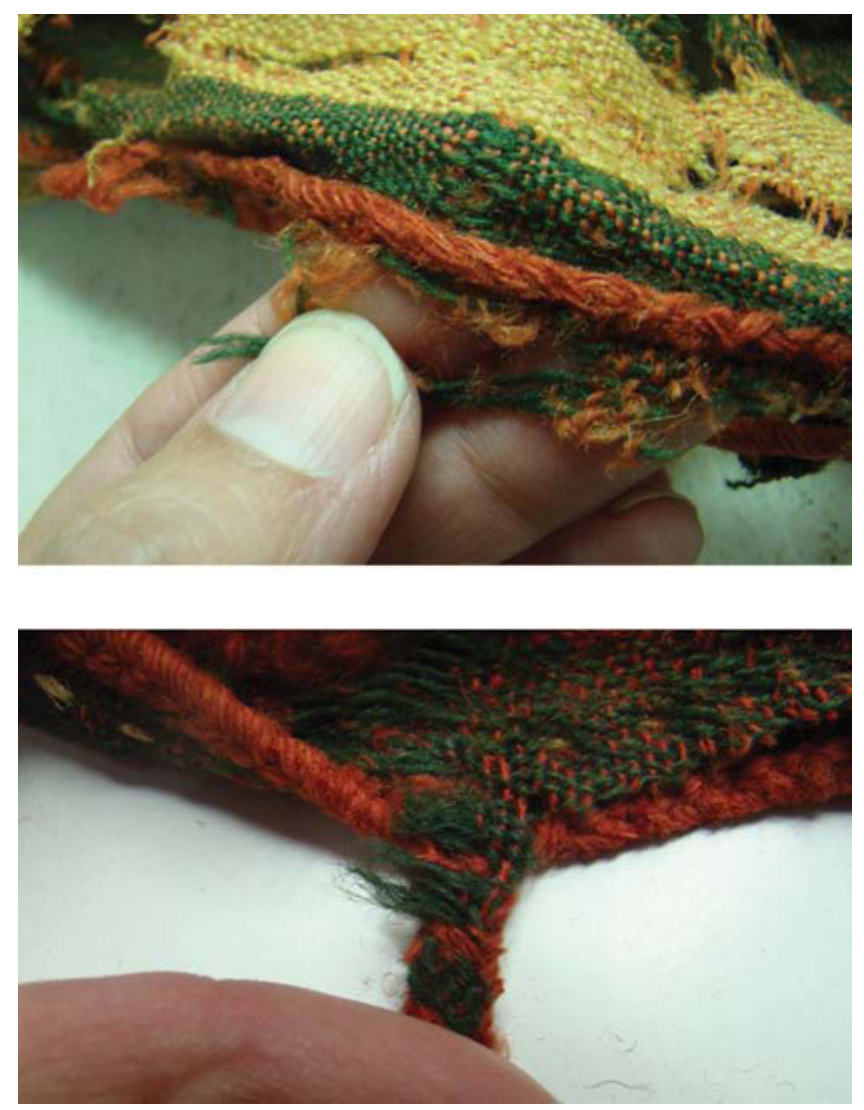

Figure 11. Tunic AF 12249. Detail of edge of waist: fragments of weave that extend beyond the finishing borders indicating the remains of sleeves. (Photo: Anne Kwaspen (C) Musée du Louvre).

century. In fact, in museum collections there are many tunics (fragments) that are embellished in modern times to create more complete garments by adding trimmings, tapestry fragments and patches, but also by imitating the type of darning work that was in use in late antique Egypt. ${ }^{14}$ To examine whether patches and darning work are original or fake, it is important to analyse the yarns used. If the weaving is made with S-spun yarns (most common in wool weaving from late antique Egypt), the sewing thread or darning thread will most probably also be S-spun. The most commonly used is S2Z as sewing thread. Finding plied $\mathrm{Z}$-spun yarns indicates it is probably an adjustment from the $2 \mathrm{O}^{\text {th }}$ century.

Besides the fact that tunic AF 12249 was made up of re-used cloth, many repairs were also carried out on this weave (fig. 12). Large tears have been sewn and patches have been applied. Various yarns were used for the sewing,

14. Examples of forgeries in tunics: the Louvre Museum: E26170, E26109, E27453 and E26299: published in Cortopassi 2013; Phoebus Foundation: KTN 2365: published in Kwaspen 2014, and Röhsska Museum: RKM 852-14: published in Erikson 1997, p. $77-83$. 


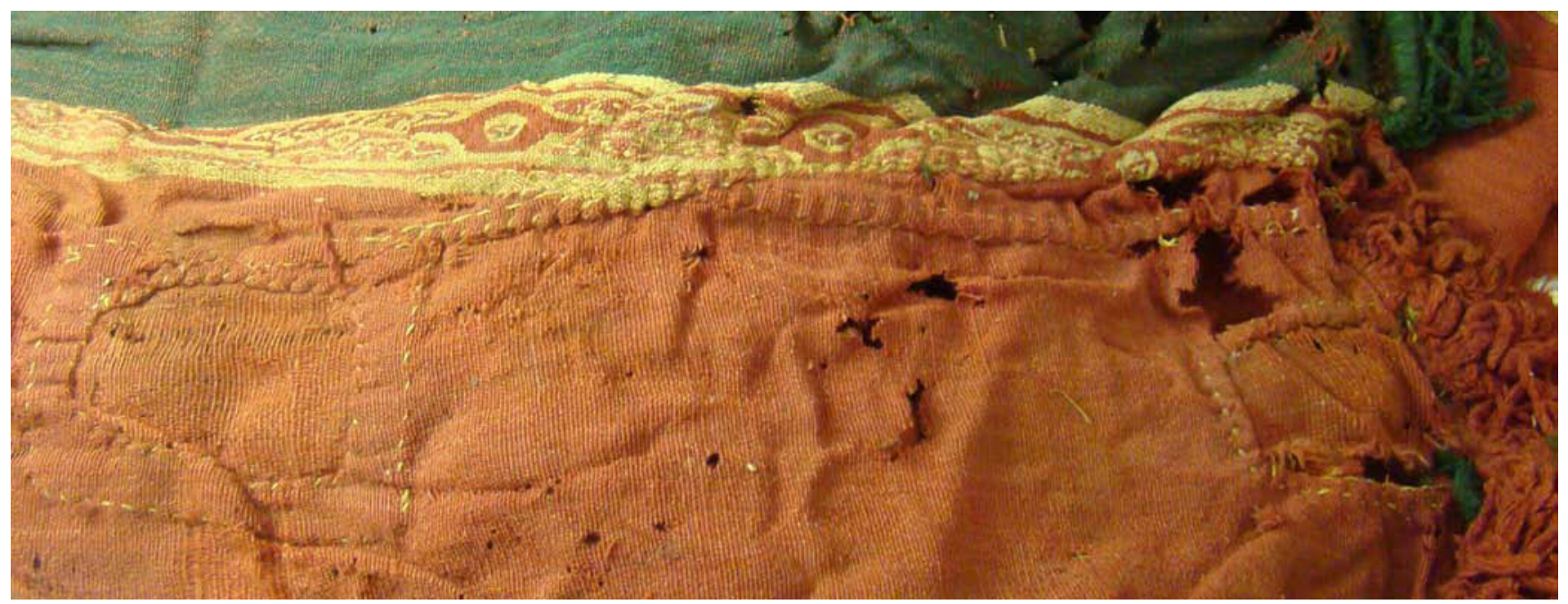

Figure 12. Tunic AF 12249. Detail of different repairs. (Photo: Anne Kwaspen (c) Musée du Louvre).

including both red (2S) and natural-coloured wool (S2Z) and also linen (S2Z). These natural-coloured yarns are in strong contrast to the red and green wool of the cloth, but looking at the other similar fragments of the Louvre Museum, E 29306, E 29308 and AF 5989, we see the same use of contrasting natural-coloured yarn. The use of S-spun yarn and the fact of the same colour use in the other fragments indicated that this tunic was remade in the late antique period. This was confirmed by radiocarbon dating of the weaving yarn, ${ }^{15}$ the sewing thread ${ }^{16}$ as well as the fringes. ${ }^{17}$ The dating of the three samples gives a clear overlap, so we can say that both the original tunic and the later remodelled tunic date from the $7^{\text {th }}$ century AD. ${ }^{18}$

\section{Conclusion}

With sleeveless tunic AF 12249 the Louvre Museum has a unique example in the collection of how pieces of clothing were re-used to create other garments (of a different type). Several features of this tunic do not match the features known from other sleeveless wool tunics. The technical analysis clearly indicated that this tunic was made from cloth of another tunic. By comparison with other woollen tunics - with or without sleeves - it could be determined which type of tunic the original tunic had been.

Re-use and repair of cloth are known practices from late antique Egypt and tunic AF 12249 is a remarkable example of its use in a piece of clothing for an adult person.

\section{Bibliography}

Bogensperger, I. (2014) "The Multiple Functions and Lives of a Textile: The Reuse of a Garment", in M. Harlow \& M.-L. Nosch (eds.), Greek and Roman Textiles and Dress. An Interdisciplinary Anthology. Ancient Textiles Series 19, Oxford, p. 335-344.

De Moor, A., Verhecken-Lammens, C., Verhecken, A. \& Maertens, H. (2008) 3500 Years of Textile Art: The Collection in HeadquARTers, Tielt.

Cortopassi, R. (2013) "La contrefaçon de tissus coptes", in A. Boud'hors \& C. Louis (eds.), Études coptes XII, Quatorzième journée d'études (Rome, 11-13 juin 2009). Cahiers de la Bibliothèque copte 18, Paris, p. 169-175.

15. 68.2\% probability: AD 645-675; 95.4\% probability (the 95.4\% probability is split into 93.1\% and $2.3 \%$ ): 93.1\% probability: AD 620-700; and 2.3\% probability: AD 740-770. I would like to thank Dominique Bénazeth for sharing with me the results of the radiocarbon dating. The radiocarbon dating was executed in KIK-IRPA (Royal Institute for Cultural Heritage), Brussels, by Mathieu Boudin.

16. 68.2\% probability: AD 645-680; 95.4\% probability (the 95.4\% probability is split into 90.0\% and 5.4\%): 90.0\%: AD 630710; and 5.4\% probability: AD 740-770.

17. 68.2\% probability: AD 615-655; 95.4\% probability: AD 590-665.

18. Bogensperger 2014, p. 335-344: the article describes a tunic fragment repaired with a sleeve? used as patch, turning the woven-to-shape tunic into a sleeveless tunic? for burial purposes? I. Bogensperger also mentions ancient sources on trade in second-hand clothing. See also Morgan 2018, p. 88-97: in the chapter on reuse F.P. Morgan quotes from ancient texts on the re-use and trade of "second-hand" clothing. 
Erikson, M. (1997) Textiles in Egypt 200-1500 A.D. Swedish Museum Collections, Gothenburg.

Fluck, C., Linscheid, P. \& Merz, S. (2000) Staatliche Museen zu Berlin-Preussischer Kulturbesitz, Skulpturensammlung und Museum für Byzantinische Kunst, Bestandskataloge, Band 1. Textilien aus Ägypten. Teil 1: Textilien aus dem Vorbesitz von Theodor Graf, Carl Schmidt und dem Ägyptischen Museum Berlin, Wiesbaden, 2000.

Haldane, E. (2009) "Waking the Dead: Scientific Analysis of an Egyptian Tunic", V\&A Conservation Journal, Spring 2009, Issue 57. Available at: http://www. vam.ac.uk/content/journals/conservation-journal/ issue-57/waking-the-dead-scientific-analysis-of-anegyptian-tunic/

Haldane, E. \& Persson, H. (2019) “The Red Woollen Tunic from Egypt in the Victoria and Albert Museum", in A. De Moor, C. Fluck \& P. Linscheid (eds.), Egypt as a Textile Hub. Textile Interrelationships in the 1st Millennium AD. Proceedings of the 1oth conference of the research group 'Textiles from the Nile Valley', Antwerp, 27-29 October 2017, Tielt, p. 246-257.

Kwaspen, A. (2014) “L'importance de l'analyse des techniques et de la connaissance des objects pour la conservation des textiles archéologiques", $B R K-$ APROA (Association Professionnelle de ConservateursRestaurateurs d'Oeuvres d'Art) Bulletin 1/2014, p. 2432. Available at: http://www.aproa-brk.org/uploads/ images/BULLETIN\%201-14COUL.pdf

Kwaspen, A. \& Verhecken-Lammens, C. (2015) "Measurements and Fitting of Egyptian Children's Tunics of the $1^{\text {st }}$ Millennium AD", in A. De Moor, C. Fluck \& P. Linscheid (eds.), Textiles, Tools and Technique of the $1^{\text {st }}$ Millennium AD from Egypt and Neighbouring Countries. Proceedings of the 8th conference of the research group 'Textiles from the Nile Valley', Antwerp, 4-6 October 2013, Tielt, p. 152-167.

Kwaspen, A. (2017) "Different Finishing Techniques of the Neck Slits on Late Antique Tunics from Egypt”, in A. De Moor, C. Fluck \& P. Linscheid (eds.), Excavating, Analysing, Reconstructing. Textiles of the $1^{\text {st }}$ Millennium AD from Egypt and Neighbouring Countries. Proceedings of the gth conference of the research group 'Textiles from the Nile Valley', Antwerp, 27-29 October 2015, Tielt, p. 196-205.
Mayer Thurman, C. \& Williams, B. (1979) Ancient Textiles from Nubia. Meroitic, X-Group, and Christian Fabrics from Ballana and Qustul. An Exhibition Organized by the Art Institute of Chicago, May 26-August 5, 1979, Chicago.

Morgan, F.P. (2018) Dress and Personal Appearance in Late Antiquity. The Clothing of the Middle and Lower Classes. Late Antique Archaeology. Supplementary Series 1, Leiden.

Pritchard, F. (2006) Clothing Culture: Dress in Egypt in the First Millennium AD. Clothing from Egypt in the Collection of The Whitworth Art Gallery, The University of Manchester, Manchester.

Pritchard, F. (2013) "A Survey of Textiles in the UK from the 1913-1914 Egypt Exploration Fund Season at Antinoupolis", in A. De Moor, C. Fluck \& P. Linscheid (eds.), Drawing the Threads Together. Textiles and Footwear of the $1^{\text {st }}$ Millennium AD from Egypt. Proceedings of the 7 th conference of the research group 'Textiles from the Nile Valley', Antwerp, 7-9 October 2011, Tielt, p. 34-55.

Verhecken-Lammens, C. (1993) "Technological Discussion”, in A. De Moor (ed.), Coptic Textiles from Flemish Private Collections, Zottegem, p. 31-52.

Verhecken-Lammens, C. (1994) “Two Coptic Wool Tunics in the Collection of the Abegg-Stiftung: A Detailed Analysis of the Weave Techniques Used", Riggisberger Berichte 2, p. 73-103.

Verhecken-Lammens, C. (1997) "Élaboration des tuniques”, in M. Bruwier (ed.), Égyptiennes. Étoffes coptes du Nil, Mariemont, p. 89-102.

Wild, J.P. (1994) “Tunic No. 4219: An Archaeological and Historical Perspective”, Riggisberger Berichte 2, p. 9-36. 